\title{
The Effects of Liquor Spirits on RNA Pol III Genes and Cell Growth of Human Cancer Lines
}

\author{
Yunfeng Yi ${ }^{1 \#}$, Junxia Lei ${ }^{2,3 \#, ~ G a n g g a n g ~ S h i ~}{ }^{4}$, Songlin Chen ${ }^{1,3}$, Yanmei Zhang,,4, \\ Zaifa Hong,5, Zhimin He ${ }^{5}$, Shuping Zhong 3,4,5* \\ ${ }^{1}$ Department of Cardiothoracic Surgery, Xiamen University Affiliated Southeast Hospital, Xiamen, China \\ ${ }^{2}$ School of Medicine, South China University of Technology, Guangzhou, China \\ ${ }^{3}$ Keck School of Medicine, University of Southern California, Los Angeles, USA \\ ${ }^{4}$ Department of Pharmacology, Shantou University Medical College, Shantou, China \\ ${ }^{5}$ Cancer Hospital and Institute of Guangzhou Medical University, Guangzhou, China \\ Email: *szhong@usc.edu
}

How to cite this paper: Yi, Y.F., Lei, J.X., Shi, G.G., Chen, S.L., Zhang, Y.M., Hong, Z.F., He, Z.M. and Zhong, S.P. (2018) The Effects of Liquor Spirits on RNA Pol III Genes and Cell Growth of Human Cancer Lines. Food and Nutrition Sciences, 9, 208-220.

https://doi.org/10.4236/fns.2018.93016

Received: February 11, 2018

Accepted: March 12, 2018

Published: March 15, 2018

Copyright $\odot 2018$ by authors and Scientific Research Publishing Inc. This work is licensed under the Creative Commons Attribution International License (CC BY 4.0).

http://creativecommons.org/licenses/by/4.0/

\section{(c) (i) Open Access}

\begin{abstract}
Alcohol consumption is a major health issue and associated with human cancers, such as liver and breast cancers. Alcohol was classed as carcinogen to human by IARC. We have performed in vivo and in vitro studies which demonstrate that diluted ethanol promotes cell proliferation and transformation and tumor formation. Consumption of liquor spirits (white wines) is a popular behavior. However, it is unclear whether liquor spirits affect cellular phenotypes of human cancers. At present study, we used diluted ethanol and liquor spirits (Sample \#1 and Sample \#2) to determine the changes in RNA polymerase III-dependent gene (Pol III gene) transcription, cell growth and colony formation in the different human cancer lines. The results indicate that low concentration of ethanol increases RNA Pol III gene transcription and rate of cell growth. However, both liquor spirits (Sample \#1 and Sample \#2) inhibit the activity of RNA Pol III genes and repress cell proliferation of the cancer lines, compared to diluted ethanol. The liquor spirits reduce the rate of colony formation of human breast cancer cells and esophageal carcinoma cells. The inhibitions of the liquor spirits to RNA Pol III genes, cell growth and colony formation are in a dose-dependent manner. These new findings suggest that the liquor spirits contain some active components to repress Pol III gene transcription and cell growth caused by ethanol in different human cancer cells.
\end{abstract}

\section{Keywords}

Ethanol, Liquor Spirits, Cancer Cells, Pol III Genes, Cell Growth, Colony Formation

${ }^{\#}$ These authors have contributed equally at the present study. 


\section{Introduction}

Numerous studies have indicated that alcohol intake is associated with human cancers in different organs, such as breast, liver, stomach, pancreas, oral cavity, pharynx, esophagus, larynx, colon and ovary [1]-[8]. Alcohol has been classed as a carcinogen to human by international agency for research on cancer (IARC) [9] [10]. This implies that there may exist an underlying mechanism, by which alcohol promotes human cancer development. However, the details of the mechanism remain to be elucidated. Nucleolar hypertrophy is a consistent cytological feature of cancer cells, where RNA polymerase III-dependent genes (Pol III genes) are transcribed. Upregulation of Pol III genes is tightly linked to cell proliferation, cell transformation and tumor development [11] [12] [13]. Our studies in vivo and in vitro have demonstrated that alcohol treatment enhances transcription of Pol III genes to promote alteration of these cellular phenotypes [13] [14] [15]. This suggests that upregulation of Pol III genes caused by ethanol plays an important role in cancer development.

Breast cancer is the major malignant neoplasms of women in the United States. Studies indicate that alcohol consumption is an established risk factor of breast cancer [16]-[21]. The relative increase in risk ranges from 5\% - 10\% $(\sim 1$ drink/10 gram/day) to $40 \%-50 \%$ ( 3 drinks/day) [22] [23]. Alcohol intake causes liver injury, such as steatosis, inflammation, fibrosis, eventually creates cirrhosis, increasing the risk of hepatocellular carcinoma (HCC) [14] [24] [25]. The fibrosis and cirrhosis of liver are the key processes during HCC development. Ethanol exposure increases cellular production of reactive oxygen species, causing cellular stress and resulting in liver injury and alcoholic liver disease (ALD) [26]. Alcohol is known to promote liver and mammary tumorigenesis [27] [28] [29] [30]. Our studies have demonstrated that alcohol activates JNK1 to upregulate Pol III gene transcription [14] [15]. Activation of JNK1 increases the rate of cell proliferation and enhances cell transformation and colony formation [12] [13]. Therefore, alcohol can be used as an agent to determine changes in these cellular phenotypes.

There is a long history of liquor spirits (white wine) consumption in China and the world. The liquor spirits of China were produced by using rice, corn, sorghum, and other grains by fermenting and distilling processes. In terms of difference of producing procedures, the liquor spirits of China were divided two types: Nong-Xiang liquors (Sample \#1) and Jiang-Xiang liquors (Sample \#2). Both of them contain slightly over $50 \%$ ethanol (v/v). Epidemiological study indicated that the workers, who tested Jiang-Xiang liquor to check its quality during the course of production, were don't found hepatic fibrosis, cirrhosis and HCC in the special crowd, compared to a group with other beverage consumption [31]. Our study indicated that alcohol-feeding of HCV NS5A transgenic mice with $3.5 \%$ ethanol induces liver steatosis and inflammation to promote HCC development [14] [30]. DEN (Diethylnitrosamine), a potent chemical hepatocarcinogen, has widely been used to induce HCC in rodents. DEN adminis- 
tration caused HCC in $100 \%$ of male mice [32]. Our studies have demonstrated that DEN increases Pol III gene transcription to enhance cell proliferation and cell transformation of mouse liver cells [33]. Male C57BL/6J mice were injected with DEN and then treated with Jiang-Xiang Liquor, compared to diluted ethanol at same concentration [34]. The incidence of HCC in Jiang-Xiang Liquor-fed group of mice is significant lower than diluted ethanol-fed group [34]. However, DEN is not really associated with human. To investigate whether the liquor spirits are indeed able to inhibit cell growth of human cancers, we have utilized two liquor spirits of China, a Nong-Xiang liquor (Sample \#1) and a Jiang-Xiang liquor (Sample \#2), to determine whether the two liquor spirits affect RNA Pol III gene transcription and cellular phenotypes of different human cancer lines. The results reveal that both liquor spirits (Sample \#1 and Sample \#2) inhibit Pol III gene activity and decrease the rates of cell proliferation of these cancer lines, compared to diluted ethanol treatment. The two liquor spirits also inhibit colony formation of human breast cancer and esophageal carcinoma lines. These studies suggest that the liquor spirits may contain some bioactive components, which are indeed of capacity of repressing ethanol-induced Pol III gene transcription and decreasing ethanol-enhanced the rates of cell growth and colony formation in different human cancer lines.

\section{Materials and Methods}

\subsection{Cell Lines and Reagents}

Human breast adenocarcinoma cell line MCF-7 (HTB-22), human colon carcinoma cell line RKO (CRL-2577), human colorectal carcinoma cell line HCT-116 (CRL-247), human colorectal adenocarcinoma cell line SW-480 (CCL-228) were from ATCC. Human esophageal squamous cell carcinoma line, KYSE-510 (ACC 374) was from DSMZ. These cell growth media were from Life Technologies Inc.

Liquor spirits (white wines) of China, a Nong-Xiang liquor (52\% ethanol, v/v) as Sample \#1 and a Jiang-Xiang liquor (53\% ethanol, v/v) as Sample \#2. Both liquor spirits were gifts from Dr. Zhenghong Xu (Jiangnan University of China). Absolute ethanol (200 proof) was from Sigma-Aldrich. The cells were treated with ethanol or liquor spirits (Sample \#1 or Sample \#2) at corresponding actual ethanol concentration $(\mathrm{mM} / \mathrm{L})$.

\subsection{RNA Isolation and RT-qPCR}

Total RNA was isolated from human breast cancer cell line (MCF-7) and esophageal carcinoma cell line (KYSE-510) treated with liquor spirits or diluted ethanol at same concentration of actual ethanol as indicated in figures using single step extraction method TRIzol reagent (Invitrogen). RNA samples were quantified and reverse-transcribed in a $20 \mu \mathrm{l}$ reaction containing $1 \times \mathrm{RT}$ (reverse transcription) buffer. After first-strand cDNA synthesis, the cDNAs were diluted in DNase-free water and real time qPCR (RT-qPCR) were performed with specific primers as described previously [12] [15] and PCR reagent kits (Bio-Rad 
Biotech) in the ABI prism 7700 Sequence Detection System. Precursor of tRNALeu and 5S rRNA transcripts were measured by RT-qPCT [13] [14].

\subsection{Cell Proliferation}

Approximately $2 \times 10^{3}$ cells per $\mathrm{ml}$ of human cancer cells (MCF-7, KYSE-510, RKO, HCT-116, SW-480) were seeded in six-well plates in triplicate. The cells were treated with liquor spirits or diluted ethanol at same concentration of actual ethanol as indicated in figures. The confluences of the cells in 6 days were about $80 \% \sim 90 \%$. The cell morphology was analyzed by microscopy using a Nikon Eclipse TE300 and Metamorph Program (Cell and Tissue Imaging Core of University of Southern California Research Center for Liver Diseases, P30 DK048522). Cells were assayed for viability and counted using a Coulter counter [12] [13].

\subsection{Cell Anchorage-Independent Growth}

MCF-7 cells and KYSE-510 cells $\left(1 \times 10^{4}\right.$ cells/well in 6 well plate $)$ were suspended in $0.35 \%(\mathrm{w} / \mathrm{v})$ agar in $10 \%$ FBS/DMEM/F12 or RIPM1640 media with specified concentrations of diluted ethanol or liquor spirit (Sample \#1 and Sample \#2) as indicated in Figure 6. Cells were fed fresh complete media with diluted ethanol, liquor spirits Sample \#1 or Sample \#2 at same concentration of actual ethanol twice weekly. Colonies were counted 2 - 3 weeks or longer after plating as described previously [11] [12].

\section{Results and Discussion}

Our previous studies have reported that diluted ethanol at $25 \sim 50 \mathrm{mM}$ (the original ethanol as 200 Proof), increases Pol III gene transcription in cell culture models [14] [15]. We have demonstrated that enhancement of Pol III gene transcription promotes cell proliferation and cell transformation [12] [13]. The Pol III gene transcription was increased in liver tumor tissues of ethanol-fed mice, compared to non-tumor tissues [14]. Repression of Pol III gene transcription results in decreasing the rates of cell proliferation and colony formation [11] [12] [13]. Therefore, reduction of the cellular phenotypic changes stands for repression of Pol III gene transcription. Study indicated that intake of a Chinese liquor spirit repressed DEN-induced liver tumor formation of mice, compared to the ethanol-fed group at same doses [34]. An epidemiological study that workers consumed the Chinese liquor spirit longer than ten years indicated that there not was hepatic fibrosis or cirrhosis in the special group, compared to a group with other beverage sources [31]. Fibrosis and cirrhosis of liver are key processes during HCC development. The liquor spirits of China are distilled liquors and made by grains through fermenting and distilling processes. It implies that the liquor spirits may have potential to repress liver cancer development.

To explore the roles of liquor spirits (Sample \#1 and Sample \#2) in alterations 
of different human cancer cells, we have determined Pol III gene transcription, cell proliferation and colony formation. The results show that diluted ethanol at $25 \mathrm{mM}$ increases Pol III gene transcription, either tRNA ${ }^{\text {Leu }}$ (Figure 1(a1) and Figure 1(b1)) or 5S rRNA (Figure 1(a2) and Figure 1(b2)) genes in human breast cancer cell line (MCF-7) (Figure 1(a)) and esophageal carcinoma cell line (KYSE-510) (Figure 1(b)). The results are consistent with our early studies [14] [15]. In contrast, the liquor spirits, both Sample \#1 and Sample \#2, significantly inhibit the gene activity at same concentration of actual ethanol $(p<0.01)$. Next, we determined the effect of liquor spirits on cell growth. The breast cancer MCF-7 cells grow to almost full confluence at diluted ethanol-treated cells from $12.5 \mathrm{mM}$ to $200 \mathrm{mM}$ of ethanol (Figure 2(a)). At lower concentration of ethanol

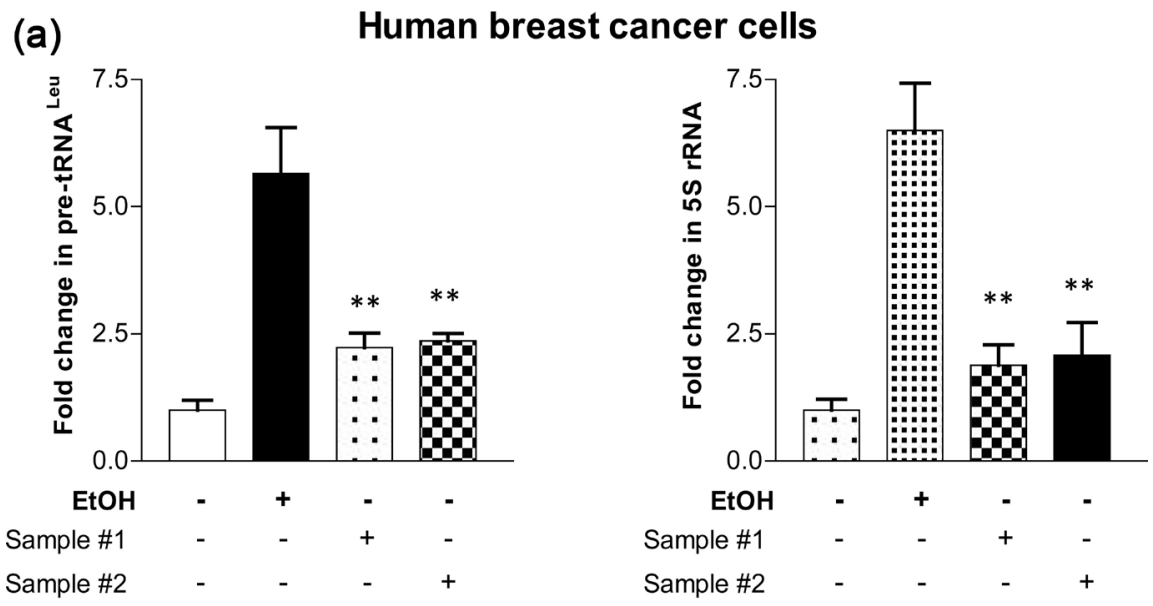

(b)

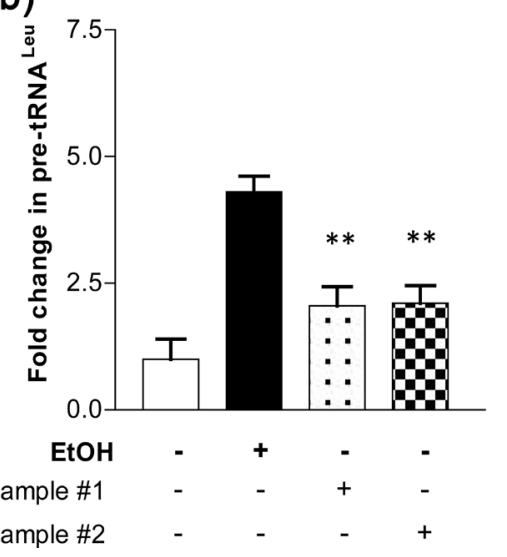

\section{Human esophageal cancinoma cells}

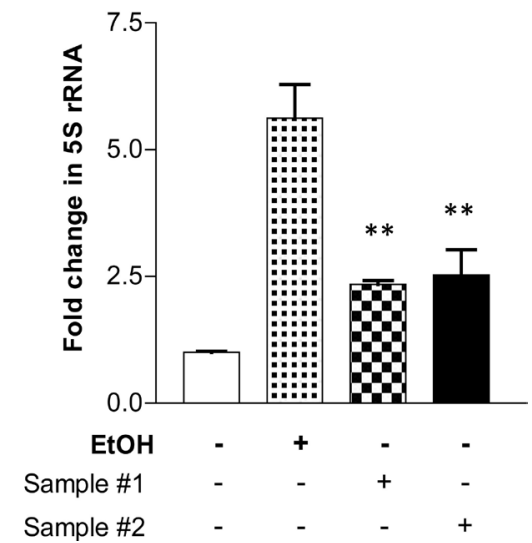

Figure 1. RNA Pol III gene transcription is inhibited by the liquor spirits. (a1) and (b1): Pol III gene, tRNA ${ }^{\text {Leu }}$ transcription in breast cancer and esophageal carcinoma cells. MCF-7 and KYSE-510 cells were grown to $85 \%$ confluency and starved in FBS-free media for $4 \mathrm{~h}$ and treated with $25 \mathrm{mM}$ diluted ethanol and liquor spirits, Sample \#1 or Sample \#2 for another hour. (a2) and (b2): Liquor spirits inhibit $5 S$ rRNA transcription. Cells were treated as above. The total RNAs from these cells were extracted to measure pre-tRNA ${ }^{\text {Leu }}, 5 \mathrm{~S}$ rRNA and GAPDH transcripts. The fold change was calculated by normalizing to the amount of GAPDH. The bars represent Mean + SE of at least three independent determinations. ${ }^{* *}: \mathrm{p}<0.01$ vs diluted ethanol. 


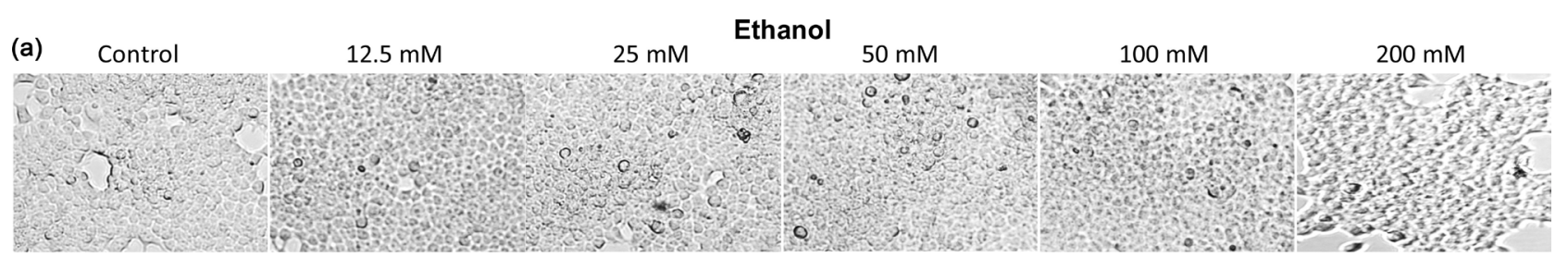

(b)

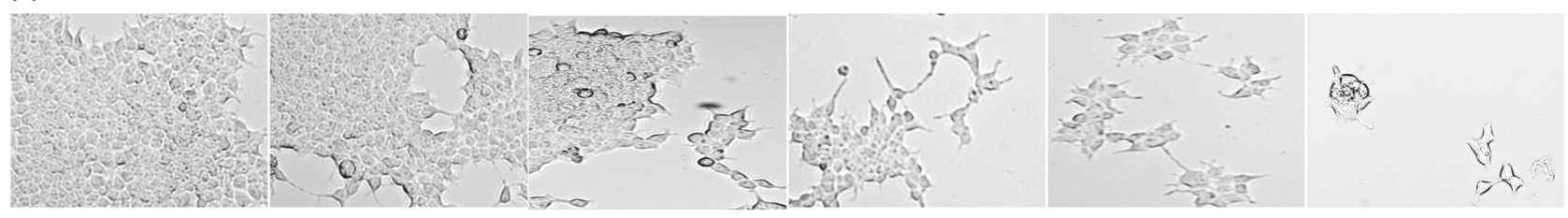

(c)

Liquor spirits: Sample \#2
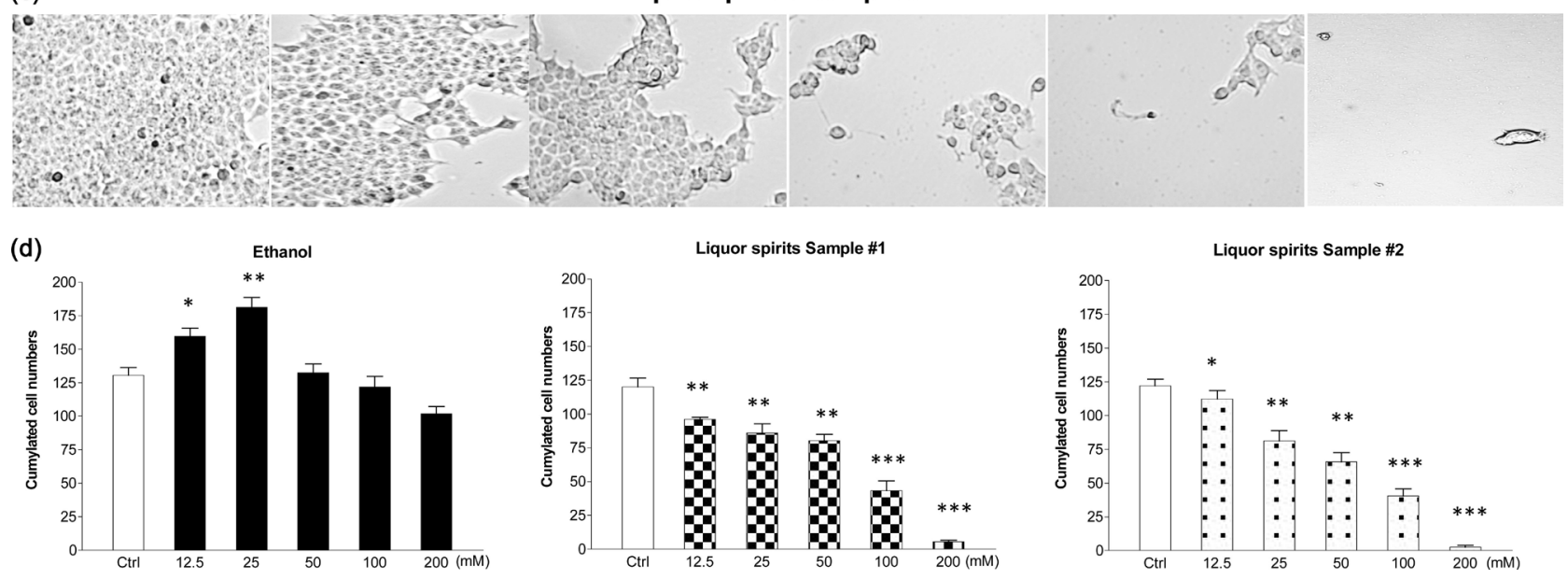

Figure 2. Liquor spirits repressed cell growth of human breast cancer line, MCF-7. (a)-(c): MCF-7 cells were treated with different amounts of diluted ethanol (a), liquor spirits Samples \#1 (b) or Sample \#2 (c) for 6 days. The concentrations of the three treatments are equal to actual ethanol (200 proof) concentration $(\mathrm{mM} / \mathrm{L})$ as indicated. The pictures were taken under microscope $(\mathrm{Ni}$ kon, Eclipse, TE300). Original magnification X 40. (d): the viability and total cell numbers were counted after plated cells 6 days. The three treatments are diluted ethanol (Left), Sample \#1 (Middle) or Sample \#2 (Right) as indicated above. ${ }^{\star}: \mathrm{p}<0.05,{ }^{* *}: \mathrm{p}<$ 0.01 , or ${ }^{* *}: \mathrm{p}<0.001$ vs control.

(from $12.5 \mathrm{mM}$ to $25 \mathrm{mM}$ ethanol), accumulation of the cells was increased (Figure 2(a) and Figure 2(d)). Then, the numbers of cells were then slightly decreased with enhancing ethanol doses (Figure 2(a) and Figure 2(d) left). While the liquor spirits, both Sample 1\# and Sample \#2, reduce the rate of MCF-7 cell growth (Figures 2(b)-(d)). At the concentration of $100 \mathrm{mM}$ ethanol of Sample \#2 almost completely inhibits the MCF-7 cell growth (Figures 2(b)-(d)), whereas Sample \#1 also dramatically represses the cells (Figure 2, middle and right). These studies show that the liquor spirits are indeed able to inhibit the activity of Pol III genes and repress cell growth of human breast cancer.

We have also determined the effects of liquor spirits on the cell growth of human esophageal carcinoma line, KYSE-510. The accumulation of the KYSE-510 cells is increased by ethanol at $12.5 \mathrm{mM}$ and $25 \mathrm{mM}$, whereas higher dose of the diluted ethanol not further increase the numbers of the cells (Figure 3(a) and Figure 3(d) left). At low dose of $12.5 \mathrm{mM}$ ethanol, both liquor spirits slightly decrease the cell growth. However, the liquor spirits dramatically reduce 


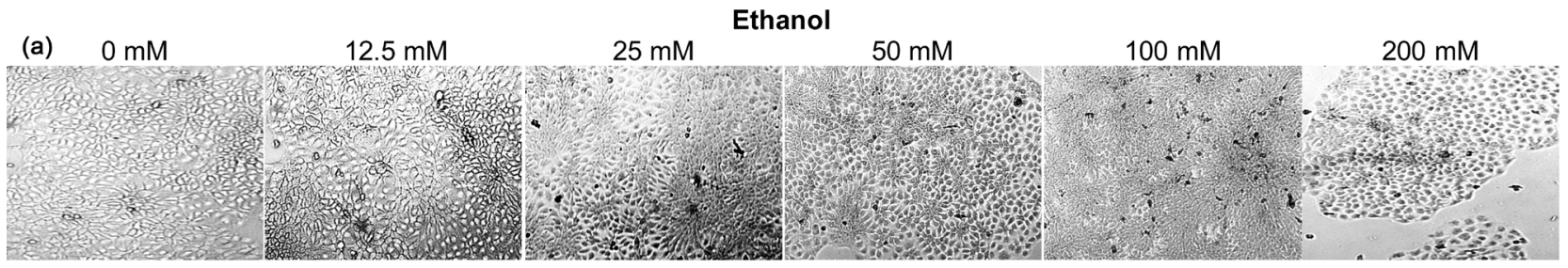

(b)

Liquor spirits: Sample \#1

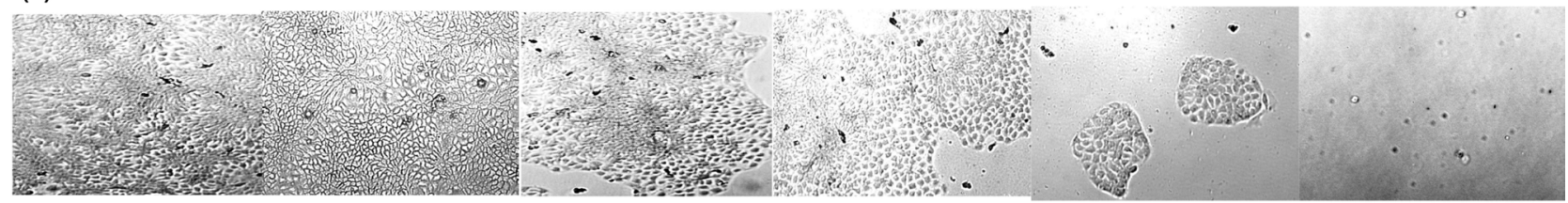

(c)

Liquor spirits: Sample \#2
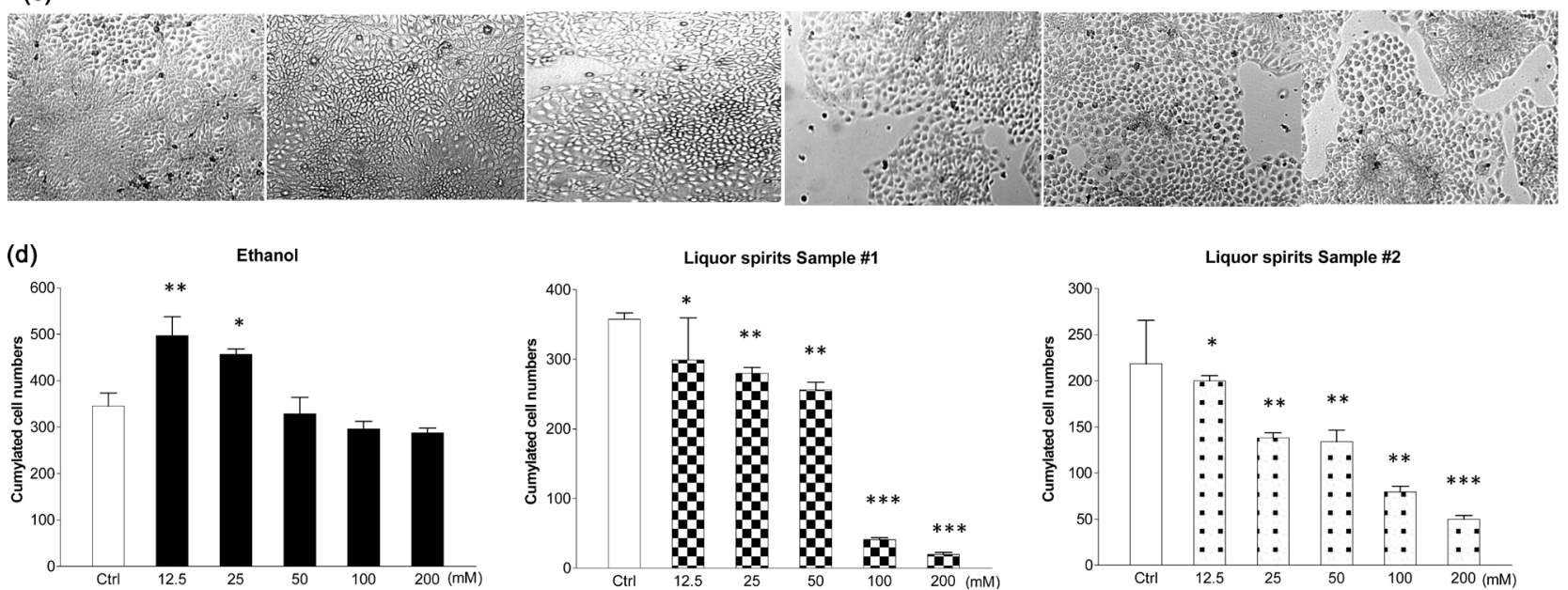

Figure 3. Repression of cell growth of human esophageal carcinoma KYSE-510 line. (a)-(c): KYSE-510 cells were treated with different amounts of diluted ethanol (a), liquor spirit Sample \#1 (b) or Sample \#2 (c) for 6 days. Original magnification X 40. (d): The viability and total cell numbers were counted after the cells plated 6 days. The three treatments are ethanol (Left), liquor spirits Sample \#1 (Middle) or liquor spirits Sample \#2 (Right). ${ }^{*}$ : $<0.05,{ }^{* *}: \mathrm{p}<0.01$, or ${ }^{\star * *}: \mathrm{p}<0.001$ vs control.

the rate of KYSE-510 cell proliferation at $100 \mathrm{mM}$ and $200 \mathrm{mM}$ ethanol (Figure 3(d) middle and right). The results indicate that this cell line is more sensitive to liquor spirits, Sample \#1 than Sample \#2 (Figures 3(b)-(d)) at the high doses of actual ethanol. To further explore the effects of the liquor spirits on cancer cell growth, we have used more human cancer lines, such as HCT-116, SW-480 and RKO. The results have shown that diluted ethanol at low doses (12.5 $\mathrm{mM}$ to 25 $\mathrm{mM}$ ) increase HCT-116 and SW-480 the rate of cell growth (Figure 4(a) and Figure 4(b)). While the liquor spirits, Sample \#1 and Sample \#2, from low doses to high one significantly reduces the acuminated numbers of the human colon carcinoma cells of HCT-116, SW-480 and RKO lines (Figure 4). In order to confirming the effects of liquor spirits on cancer cells, we have additionally tested the effects of the liquor spirits on the tumor stem cells of mouse liver (TSCML). The two liquor spirits reduce the rate of cell proliferation of TSCML (Figure 5). But, the repressing cell growth of TSCML by liquor spirit, Sample \#2 is more significant than Sample \#1 (Figure 5). Together, the above studies have shown that ethanol increases the rate of cell proliferation of the cancer cell lines 
(a)
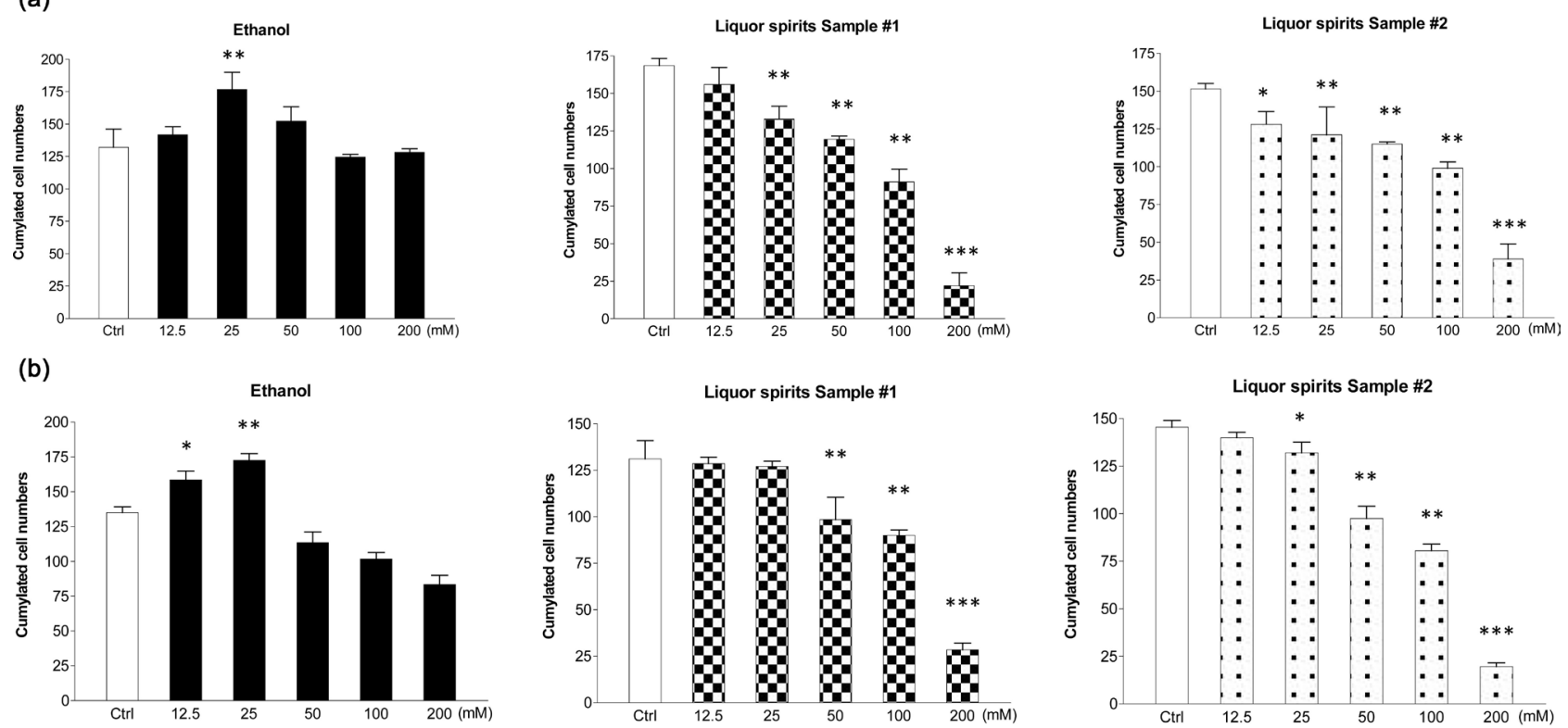

(c)

Liquor spirits Sample \#1

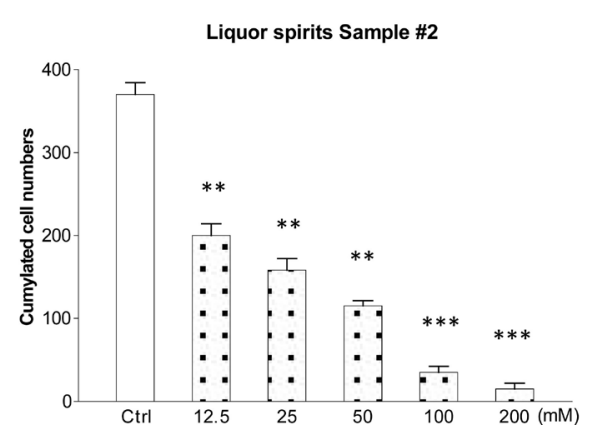

Figure 4. Liquor spirits decrease the rates of cell growth of human colorectal carcinoma lines. Human colorectal carcinoma HCT-116 cells (a), human colorectal adenocarcinoma SW-480 cells (b) and human colorectal carcinoma RKO cells (c) were treated with different amounts of diluted ethanol (a), liquor spirits Sample \#1 (b) or liquor spirits Sample \#2 (c) for 6 days. The viability and total cell numbers were counted after the cells plated 6 days. ${ }^{*}: \mathrm{p}<0.05,{ }^{* *}: \mathrm{p}<0.01$, or ${ }^{* *}$ : $\mathrm{p}<0.001$ vs control.

at lower concentration. Although the accumulation of the KYSE-510 cells is decreased at high dose of diluted ethanol, the higher dose of ethanol induces cellular apoptosis. While liquor spirits, both Samples \#1 and Sample \#2, display the inhibition of cell growth of different cancer lines from low to high concentration. The inhibiting roles of liquor spirits in Pol III gene transcription and cell growth are in a dose-dependent manner.

As inhibiting Pol III gene transcription is able to repress cell transformation [11] [12] [33], ethanol treatment promotes the transformation of normal cells and increases colony formation of cancer cells [11] [12]. Here, our data indicate that liquor spirits inhibit Pol III gene transcription (Figure 1(a)). Therefore, we further determine the effect of liquor spirits on colony formation of the human cancer cells. We seeded the human breast cancer line, MCF-7 cells (Figure 6 top) and human esophageal carcinoma line, KYSE-510 cells (Figure 6 bottom) in soft agar and treated the cells with the liquor spirits, respectively. The results indicate that the liquor spirits, either Sample \#1 (Figure 6 left) or Sample \#2 


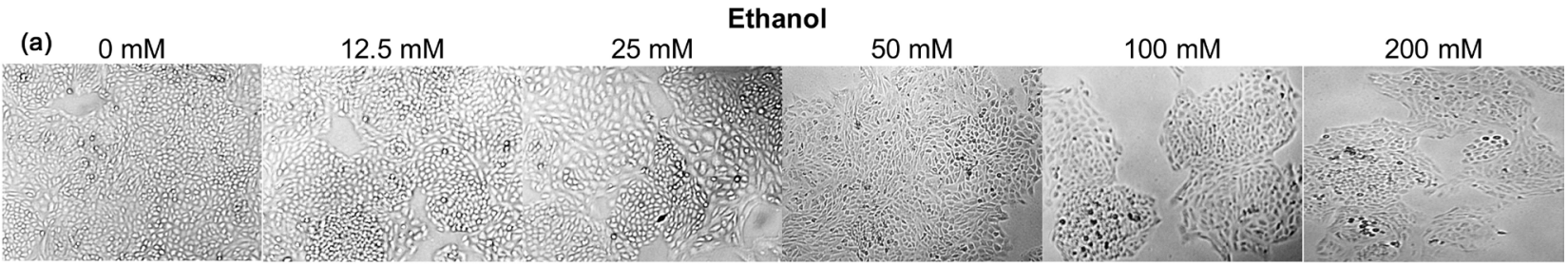

(b)

Liquor spirits: Sample \#1

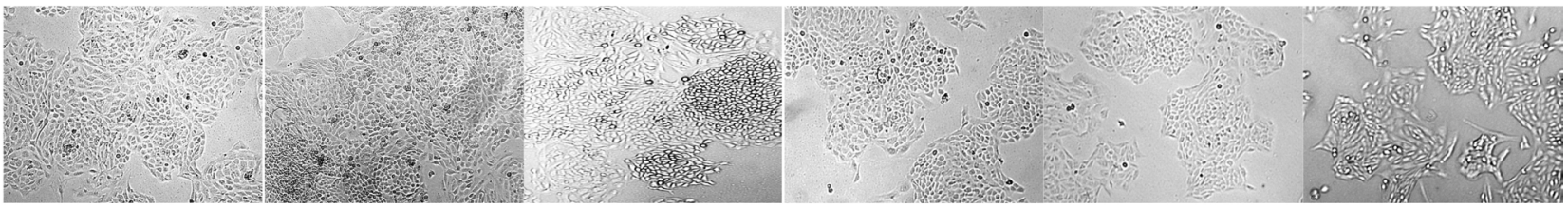

(c)

Liquor spirits: Sample \#2
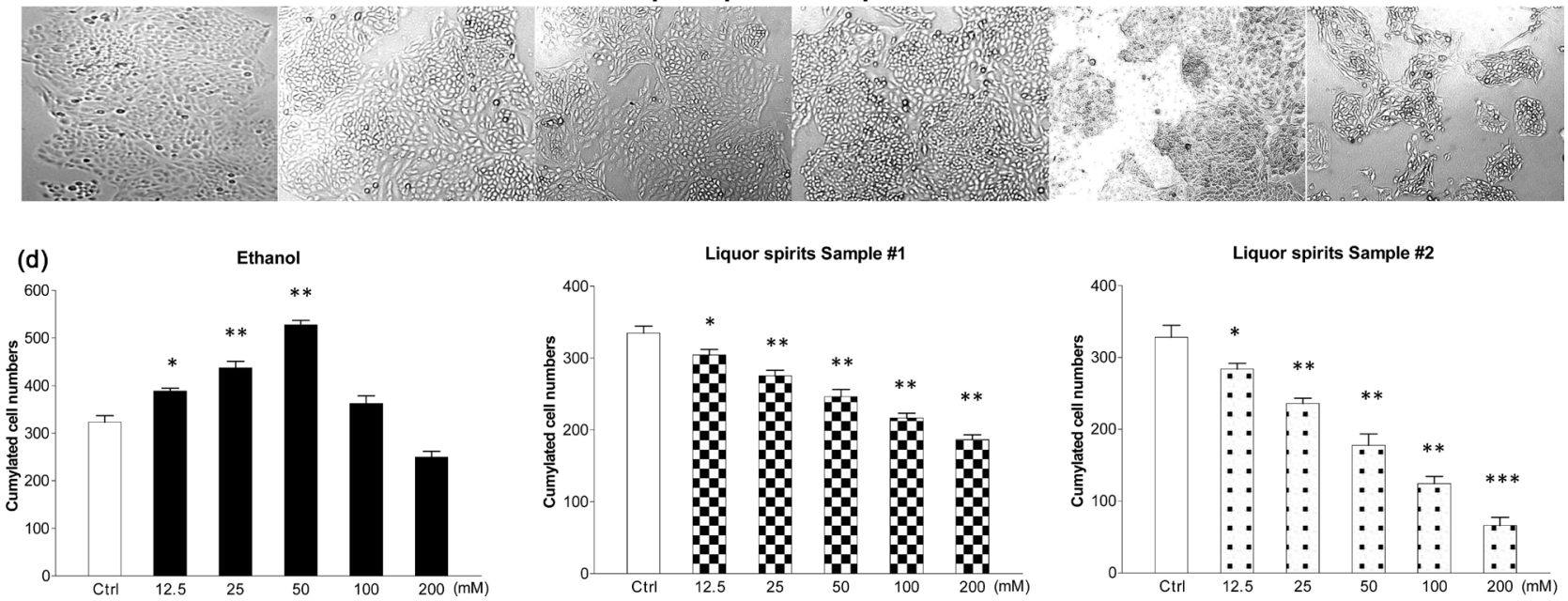

Figure 5. Liquor spirits inhibited cell growth of TSCML line. (a)-(c): TSCML (tumor stem cells of mouse liver) cells were seeded in into 6-well plate and cultured in 10\% FBS/DMEM medium with diluted ethanol (a), liquor spirits Samples \#1(b) or Sample \#2 (c) for 6 days. The concentrations of the three treatments are equal to actual ethanol $(\mathrm{mM} / \mathrm{L})$ as indicated. Original magnification $\mathrm{X}$ 40. (d): The viability and total cell numbers were counted after the cells plated 6 days. The three treatments are diluted ethanol (Left), liquor spirits Samples \#1 (Middle) or liquor spirits Samples \#2 (Right) as indicated. At lower concentration of diluted ethanol from $12.5 \mathrm{mM}$ to $50 \mathrm{mM}$, numbers of the cells were increased (Left), whereas liquor spirits Samples \#1 and liquor spirits Sample \#2 repress the cell growth from low concentration to high. ${ }^{*}$ : $<<0.05,{ }^{* *}: \mathrm{p}<0.01$, or ${ }^{* * *}$ : $\mathrm{p}<0.001$ vs control.

(Figure 6 right) inhibit colony formation of the human cancer cells (Figure 6).

In summary, the present studies indicate that the liquor spirits display the effects of repression on Pol III gene transcription, cell proliferation and colony formation in different human cancer lines. It implies that liquor spirits may contain some bioactive compounds which inhibit ethanol-induced RNA Pol III gene activity and ethanol-caused cancer cellular phenotypic alteration. This is the first report on the liquor spirits repressing cell growth of different human cancer lines. It suggests that identifying the bioactive compounds of the liquor spirits and enhancing the ratio of the compounds during producing processes will benefit drinkers to prevent cancer development.

\section{Acknowledgements}

This work was supported by CNJ14C007 to Y.Y. 

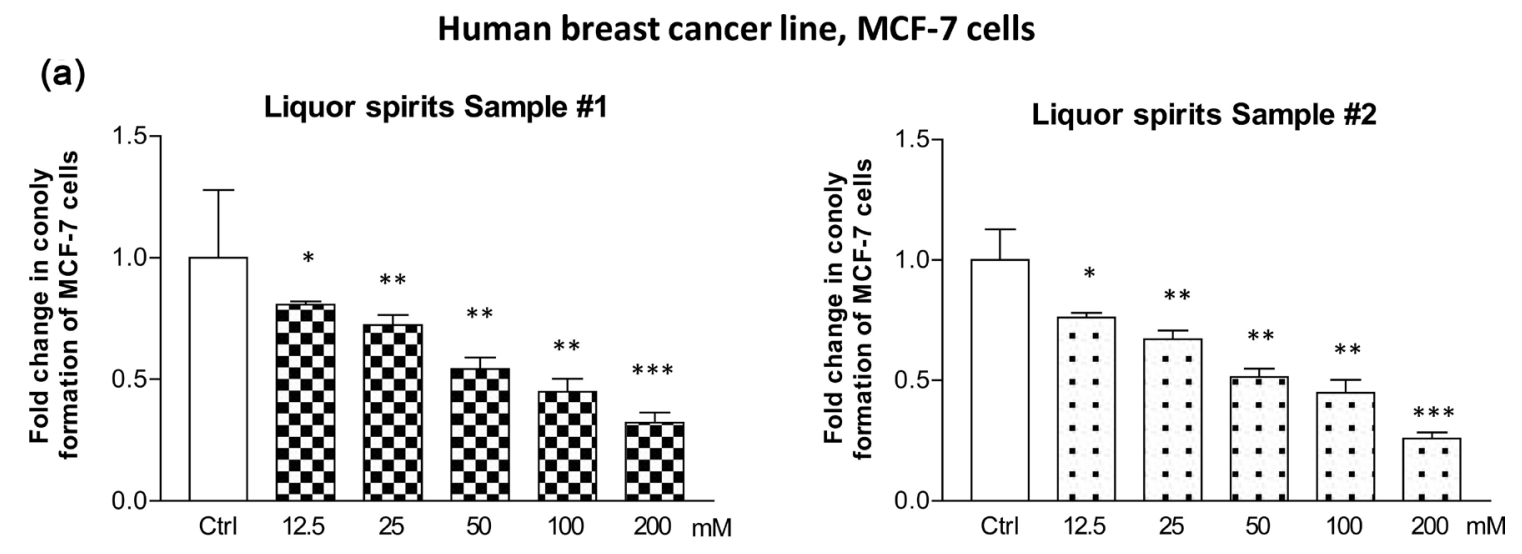

(b)

Human esophageal carcinoma line, KYSE-510 cells
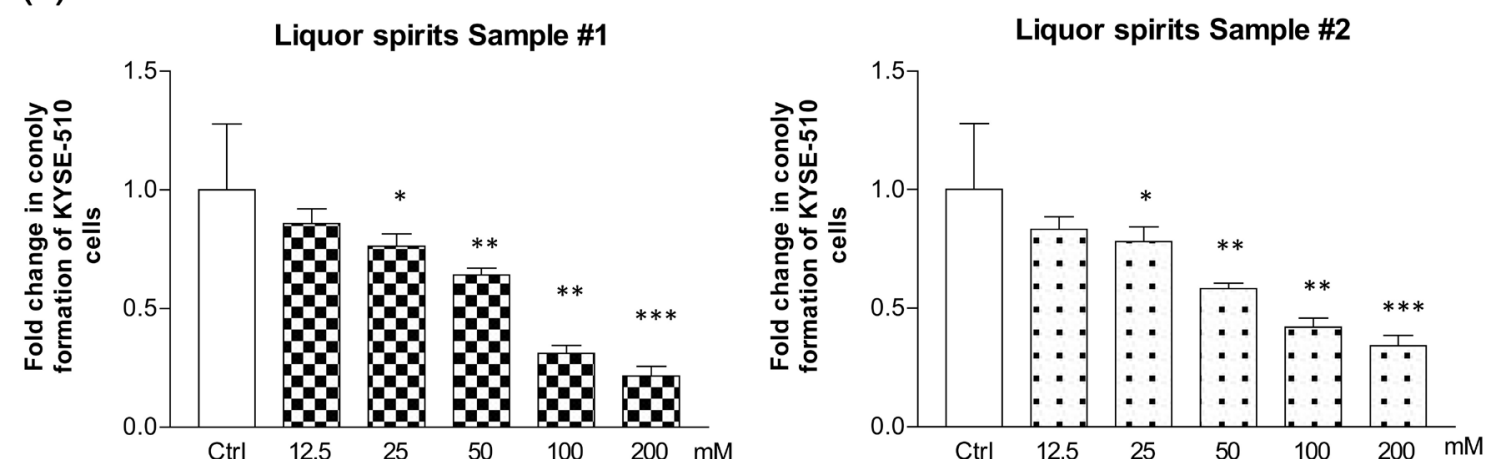

Figure 6. Inhibition of colony formation of human cancer cells by liquor spirits. MCF-7 cells (Top) and KYSE-510 cells (Bottom) were poured in triplicate into 6-well plate with $0.35 \%$ agar containing the liquor spirits Sample \#1 (a1 and b1) or Sample \#2 (a2 and b2) in the media as indicated. The cells were analyzed for colony formation in soft agar after plated 2 - 3 weeks. Both liquor spirits reduced the rates of colony formation of MCF-7 and KYSE-510 cells. ${ }^{*}: \mathrm{p}<0.05,{ }^{* *}: \mathrm{p}<0.01$, or ${ }^{* * *}: \mathrm{p}<0.001$ vs control.

\section{Declaration of Interest}

The authors declare that they have no conflict of interest.

\section{Author Contributions}

$\mathrm{YY}$ and SZ involved in conception and design and in analysis and interpretation of data. GS, and SZ involved in data acquisition and in writing and reviewing of the manuscript. YY, JL, SC, YZ and ZH involved in development of methodology. SC, JL, YZ, YY provided administrative, technical, or material support. SZ and GS supervised the study. All authors read and approved the final manuscript.

\section{References}

[1] Allen, N.E., Beral, V., Casabonne, D., Kan, S.W., Reeves, G.K., Brown, A. and Green, J. (2009) Moderate Alcohol Intake and Cancer Incidence in Women. Journal of the National Cancer Institute, 101, 296-305. https://doi.org/10.1093/jnci/djn514

[2] Connor, J. (2017) Alcohol Consumption as a Cause of Cancer. Addiction, 112, 222-228. https://doi.org/10.1111/add.13477 
[3] Scoccianti, C., Straif, K. and Romieu, I. (2013) Recent Evidence on Alcohol and Cancer Epidemiology. Future Oncology, 9, 1315-1322. https://doi.org/10.2217/fon.13.94

[4] Shi, G.G., and Zhong, S. (2017) Alcohol-Associated Cancer and Deregulation of Pol III Genes. Gene, 612, 25-28. https://doi.org/10.1016/j.gene.2016.09.046

[5] Yi, Y.F., Huang, C.H., Zhang, Y.M., Tian, S.K., Lei, J.X., Chen, S.L., Shi, G.G., Wu, Z.D., Xia, N.S. and Zhong, S. (2017) Exploring a Common Mechanism of Alcohol-Induced Deregulation of RNA Pol III Genes in Liver and Breast Cells. Gene, 626, 309-318. https://doi.org/10.1016/j.gene.2017.05.048

[6] Lei, J.X., Chen, S.L. and Zhong, S. (2017) Abnormal Expression of TFIIIB Subunits and RNA Pol III Genes Is Associated with Hepatocellular Carcinoma. Liver Research, 2, 112-120. https://doi.org/10.1016/j.livres.2017.08.005

[7] Fang, Z., Yi, Y., Shi, G., Li, S., Chen, S., Lin, Y., Li, Z., He, Z., Li, W. and Zhong, S. (2017) Role of Brf1 Interaction with ERa, and Significance of Its Overexpression in Human Breast Cancer. Molecular Oncology, 11, 1752-1767. https://doi.org/10.1002/1878-0261.12141

[8] Zhang, Y., Wu, H., Yang, F., Ning, J., Li, M., Zhao, C., Zhong, S., Gu, K. and Wang, H. (2018) Prognostic Value of the Expression of DNA Repair-Related Biomarkers Mediated by Alcohol in Gastric Cancer Patients. The American Journal of Patholo$g y$, 188, 367-377. https://doi.org/10.1016/j.ajpath.2017.10.010

[9] IARC. (2011) IARC Monographs on the Evaluation of Carcinogenic Risks to Humans, Vol 100, A Review of Human Carcinogens. International Agency for Research on Cancer, Lyon. http://monographs.iarc.fr/ENG/Monographs/PDFs/index.php

[10] Cogliani, V.J., Baan, R., Straif, K., Crosse, Y., Lauby-Secretan, B., El Ghissassi, F., Bouvard, V., Benbrahim-Tallaa, L., Guha, N., Freeman, C., Galichet, L. and Wild, C.P. (2011) Preventable Exposures Associated with Human Cancers. Journal of the National Cancer Institute, 103, 1827-1839. https://doi.org/10.1093/jnci/djr483

[11] Johnson, S.A., Dubeau, L. and Johnson, D.L. (2008) Enhanced RNA Polymerase III-Dependent Transcription Is Required for Oncogenic Transformation. Journal of Biological Chemistry, 283, 19184-19191. https://doi.org/10.1074/jbc.M802872200

[12] Zhong, S. and Johnson, D.L. (2009) The JNKs Differentially Regulate RNA Polymerase III Transcription by Coordinately Modulating the Expression of All TFIIIB Subunits. Proceedings of the National Academy of Sciences of the United States of America, 106, 12682-12687. https://doi.org/10.1073/pnas.0904843106

[13] Zhong, S., Fromm, J. and Johnson, D.L. (2007) TBP Is Differentially Regulated by JNK1 and JNK2 through Elk-1, Controlling c-Jun Expression and Cell Proliferation. Molecular and Cellular Biology, 27, 54-64. https://doi.org/10.1128/MCB.01365-06

[14] Zhong, S., Machida, K., Tsukamoto, H. and Johnson, D.L. (2011) Alcohol Induces RNA Pol III-Dependent Transcription through c-jun by Coregulating TBP and Brf1 Expression. Journal of Biological Chemistry, 286, 2393-2401. https://doi.org/10.1074/jbc.M110.192955

[15] Zhang, Q., Jin, J., Zhong, Q., Yu, X.L., Levy, D. and Zhong, S. (2013) ERa Mediates Alcohol-Induced Deregulation of Pol III Genes in Breast Cancer Cells. Carcinogenesis, 34, 28-33. https://doi.org/10.1093/carcin/bgs316

[16] Hamajima, N., Hirose, K., Tajima, K., et al. (2002) Alcohol, Tobacco and Breast Cancer-Collaborative Reanalysis of Individual Data from 53 Epidemiological Studies, Including 58,515 Women with Breast Cancer and 95,067 Women without the Disease. British Journal of Cancer, 87, 1234-1245. 
https://doi.org/10.1038/sj.bjc.6600596

[17] MacMahon, B. (2006) Epidemiology and the Causes of Breast Cancer. International Journal of Cancer, 118, 2373-2378. https://doi.org/10.1002/ijc.21404

[18] Petri, A.L., Anne, T., Michael, G., Ditte, J., Susanne, H., Thorkild, S. and Moeten, G. (2004) Alcohol Intake, Type of Beverage, and Risk of Breast Cancer in Pre-And Postmenopausal Women. Alcoholism, Clinical and Experimental Research, 28, 1084-1090. https://doi.org/10.1097/01.ALC.0000130812.85638.E1

[19] Singletary, K.W. and Gapstur, S.M. (2001) Alcohol and Breast Cancer: Review of Epidemiologic and Experimental Evidence and Potential Mechanisms, JAMA, 286, 2143-2151. https://doi.org/10.1001/jama.286.17.2143

[20] Chen, W.Y., Rosner, B., Hankinson, S.E., Colditz, G.A. and Willett, W.C. (2011) Moderate Alcohol Consumption during Adult Life Drinking Patterns, and Breast Cancer Risk. JAMA, 306, 1884-1890. https://doi.org/10.1001/jama.2011.1590

[21] Seitz, H.K., Pelucchi, C., Bagnardi, V. and La Vecchia, C. (2012) Epidemiology and Pathophysiology of Alcohol and Breast Cancer: Update 2012. Alcohol, 47, 204-212. https://doi.org/10.1093/alcalc/ags011

[22] Singletary, K.M., Nelshoppen, J. and Wallig, M. (1995) Enhancement by Chronic Ethanol Intake of N-methyl Nitrosourea-Induced Rat Mammary Tumorigenesis. Carcinogenesis, 16, 959-964. https://doi.org/10.1093/carcin/16.4.959

[23] Watabiki, T., Okii, Y., Tokiyasu, T., Yoshimura, S., Yoshida, M., Akane, A., Shikata, N. and Tsubura, A. (2000) Long Term Ethanol Consumption in ICR Mice Causes Mammary Tumor in Females and Liver Fibrosis in Males. Alcoholism, Clinical and Experimental Research, 24, 117S-122S.

[24] Lieber, C. (2000) Hepatic, Metabolic, and Nutritional Disorders of Alcoholism: From Pathogenesis to Therapy. Critical Reviews in Clinical Laboratory Sciences, 37, 551-584. https://doi.org/10.1080/10408360091174312

[25] Zhong, Q., Xi, S.Y., Liang, J.Z., Shi, G.G., Huang, Y., Zhang, Y.M., Levy, D. and Zhong, S. (2016) The Significance of Brf1 Overexpression in Human Hepatocellular Carcinoma. Oncotarget, 7, 6243-6254. https://doi.org/10.18632/oncotarget.6668

[26] Purohit, V., Khalsa, J. and Serrano, J. (2005) Mechanisms of Alcohol-Associated Cancers: Introduction and Summary of the Symposium. Alcohol, 35, 155-160. https://doi.org/10.1016/j.alcohol.2005.05.001

[27] Deandrea, S., Talamini, R., Foschi, R., Montella, M., Dal Maso, L., Falcini, F., La Vecchua, C., Franceschi, S. and Negri, E. (2008) Alcohol and Breast Cancer Risk Defined by Estrogen and Progesterone Receptor Status: A Case-Control Study. Cancer Epidemiology, Biomarkers \& Prevention, 17, 2025-2028. https://doi.org/10.1158/1055-9965.EPI-08-0157

[28] Suzuki, R., Orsini, N., Mignone, L., Saji, S. and Wolk, A. (2008) Alcohol Intake and Risk of Breast Cancer Defined by Estrogen and Progesterone Receptor Status-A Meta-Analysis of Epidemiological Studies. International Journal of Cancer, 122, 1832-1841. https://doi.org/10.1002/ijc.23184

[29] Singletary, K.W., McNary, M.Q., Odoms, A.M., Nelshoppen, J. and Wallig, M.A. (1991) Ethanol Consumption and DMBA-Induced Mammary Carcinogenesis in Rats. Nutrition and Cancer, 16, 13-23. https://doi.org/10.1080/01635589109514136

[30] Machida, K., Tsukamoto, H. and Mkrtchyan, L. (2009) Toll-Like Receptor 4 Mediates Synergism between Alcohol and HCV in Hepatic Oncogenesis Involving Stem Cell Marker Nanog. Proceedings of the National Academy of Sciences, 106, 1548-1553. https://doi.org/10.1073/pnas.0807390106 
[31] Wu, J., Cheng, M.L., Zhang, G.H., et al. (2002) Epidemiological and Histopathological Study of Relevance of Guizhou Maotai Liquor and Liver Diseases. World Journal of Gastroenterology, 8, 571-574. https://doi.org/10.3748/wjg.v8.i3.571

[32] Naugler, W.E., Sakarai, T., Kin, S., Maeda, K., Kim, K., Elsharkawy, A. and Karin (2007) Gender Disparity in Liver Cancer Due to Sex Differences in MyD88-Dependent IL-6 Production. Science, 317, 121-124. https://doi.org/10.1126/science.1140485

[33] Zhong, Q., Shi, G.G., Zhang, Q.S., Zhang, Y.M., Levy, D. and Zhong, S. (2013) Role of Phosphorylated Histone H3 Serine 10 in DEN-Induced Deregulation of Pol III Genes and Cell Proliferation and Transformation. Carcinogenesis, 34, 2460-2469. https://doi.org/10.1093/carcin/bgt219

[34] Yi, X., Li, L., Yang, C.Z., Lu, Y.Y. and Cheng, M.L. (2014) Maotai Ameliorates Diethylnitrosamine-Initiated Hepatocellular Carcinoma Formation in Mice. PLoS ONE, 9, e93599. https://doi.org/10.1371/journal.pone.0093599 